DOI: 10.34015/2523-4552.2019.2.15

УдК 343.8

Махніцька К. Г.,

аспірант кафедри кримінального

права та правосуддя Міжнародного

економіко-гуманітарного університету

імені академіка Степана Дем'янчука

\title{
ПРО СОЦІАЛЬНО-ПРАВОВУ ПРИРОДУ ЗАБОРОН ЩОДО ПРОДУКТІВ ХАРЧУВАННЯ ДЛЯ ЗАСУДЖЕНИХ, ПОЗБАВЛЕНИХ ВОЛІ, ЯКІ ВОНИ МАЮТЬ ПРАВО ЗБЕРІГАТИ ПРИ СОБІ
}

У статті піддано аналізу ті норми кримінально-виконавчого права, що стосуються встановлення заборон стосовно продуктів харчування, виробів i речовин, які засуджені можуть отримувати в посилках (передачах), купувати в крамницях установ виконання покарань та зберігати при собі, а також розроблено науково обгрунтовані пропозиції щодо зменшення їх переліку на нормативно-правовому рівні.

Ключові слова: заборонені продукти, вироби і речовини; засуджений; позбавлення волі; персонал колоній; право особи; обов'язок особи; кримінальновиконавче законодавство.

В статье осуществлен анализ норм уголовно-исполнительного права, касающихся установления запретов относительно продуктов, изделий и веществ, которые осужденные могут получать в посылках, покупать в магазинах учреждений исполнения наказаний и хранить при себе, а также разработаны научно обоснованные предложения, направленные на уменьшение их перечня на нормативно-правовом уровне.

Ключевые слова: запрещенные продукты питания, изделия и вещества; осужденный; лишение свободы; персонал колоний; право лица; обязанность лища; уголовно-исполнительное законодательство.

Постановка проблеми. У квітні 2014 року Україна прийняла низку змін і доповнень до кримінальновиконавчого законодавства, що спрямовані на приведення умов виконання - відбування покарання у виді позбавлення волі у відповідність до європейських стандартів [1]. Відповідні механізми реалізації цього завдання визначені, зокрема, i в Концепції реформування (розвитку) пенітенціарної системи України, схваленій розпорядження Кабінету Міністрів України у вересні 2017 року [2]. При цьому однією із системних вимог, що ставить європейська спільнота перед Україною, є суттєве покращення харчування осіб, які тримаються в місцях позбавлення волі. Важливим у зв'язку 3 цим $\epsilon$ положення Європейських пенітенціарних правил (далі - ЄПП), у п. 22.1 
яких зазначено, що засуджені мають забезпечуватися комплексним харчуванням з урахуванням їх віку, стану здоров'я, релігії, культури та характеру їхньої роботи. При цьому вимоги щодо раціонального харчування, включаючи мінімальну кількість калорій та білків, визначаються національним законодавством [3].

Разом 3 тим, як свідчить практика, саме харчування засуджених, які відбувають покарання у місцях позбавлення волі в Україні, завжди $є$ предметом негативної оцінки відповідних міжнародних експертів [4] та рішень Європейського суду 3 прав людини (ЄС ПП) [5]. При цьому об'єктом критики в цьому контексті $€$ й визначені в нормах кримінальновиконавчого права заборони щодо певних видів продуктів харчування, які мають право зберігати при собі засуджені до позбавлення волі (частина сьома статті 102, статті 108, 112 Кримінально-виконавчого кодексу України (КВК) та додатки 3, 5 до Правил внутрішнього розпорядку установ виконання покарань (ПВР УВП)) [6].

Постановка завдання. 3 огляду на викладене, тема цієї наукової статті $є$ актуальною та такою, що має теоретико-прикладне значення. При цьому головним завданням $\epsilon$ розроблення науково обгрунтованих заходів, спрямованих на вдосконалення правового механізму з питань забезпечення харчування засуджених у місцях позбавлення волі 3 урахуванням вимог міжнародного права.

Аналіз останніх досліджень і публікацій. Результати вивчення наукової літератури свідчать про те, що зазначеними питаннями активно займаються як кримінологи, так i вчені кримінально-виконавчого профілю. До них можна віднести таких, як О.М. Бандурка, І. Г. Богатирьов, В. В. Василевич, В. В. Голіна, Б. М. Головін, Т. А. Денисова, О. М. Джужа, О. Г. Колб, І. М. Копотун, В. М. Конопельський, О.В.Лисодєд, В.А.Меркулова, А. В. Савченко, А. Х. Степанюк, М. С. Пузирьов, I. С. Яковець та інші. Поряді 3 цим, ураховуючи зазначені тенденції розвитку цього суспільно небезпечного явища, що склалися сьогодні в місцях позбавлення волі, а також роль заборонених предметів у механізмі вчинення злочинів засудженими, які тримаються в УВП, слід визнати, що актуальність, теоретичне та практичне значення означеної тематики дослідження $\epsilon$ очевидними, що й стало вирішальним при виборі теми цієї наукової статті.

Виклад основного матеріалу. Як зазначено в частині першій статті 108 КВК України, засуджені до позбавлення волі мають право придбавати за безготівковим розрахунком продукти харчування на гроші, зароблені в колоніях, одержані за переказами, за рахунок пенсії та іншого доходу без обмежень їх обсягу. При цьому їх перелік визначається нормативно-правовими актами Miністерства юстиції України (частина сьома статті 108 КВК), що, з урахуванням вимог пункту 14 статті 92 Конституції України, відповідно до якої виключно законами визначається діяльність органів та установ виконання покарань, не можна визнати правильним підходом законодавця з означених питань. Зокрема, у розділі 1 Переліку продуктів харчування, виробів і речовин, які засуджені можуть отримувати в посилках (передачах), купувати в крамницях установ виконання покарань та зберігати при собі (додаток 5 до ПВР 
УВП (пункт 1 розділу V)) зазначено про те, що це $\epsilon$ продукти харчування фабричного (заводського) виготовлення в скляній або металевій тарі 3 діючим терміном реалізації, які не потребують додаткового приготування шляхом термічної обробки та можуть зберігатися за кімнатної температури, свіжі фрукти та овочі (огірки, помідори, цибуля, часник, перець, капуста, морква та зелень), а також чай та тютюнові вироби фабричного розфасування.

У зв'язку 3 цим виникає питання, які це продукти, що не потребують додаткової термічної обробки, перелік яких у ПВР УВП не встановлено.

Водночас відповідно до вимог частини першої статті 19 Конституції України правовий порядок грунтується на засадах, згідно з якими ніхто не може бути примушений робити те, що передбачається законодавством [8], а, як це витікає зі змісту частини першої статті 107 КВК України, засуджені, які відбувають покарання у виді позбавлення волі, мають право в порядку, установленому цим Кодексом i нормативно-правовими актами Міністерства юстиції України, одержувати інформацію та роз'яснення про умови відбування і порядок виконання покарання у виді позбавлення волі. Тобто в цій ситуації слід у переліку заборонених продуктів харчування (додаток 5 до ПВР УВП) чітко вказати, які із них засуджені не можуть тримати при собі.

Цей висновок грунтується на таких аргументах:

1. Як випливає зі змісту частини першої статті 107 КВК України, засуджені до позбавлення волі мають право розпоряджатися своїми коштами, придбавати, володіти і розпо- ряджатися предметами, речами та виробами, а також одержувати посилки, бандеролі, грошові перекази.

Виходячи з цього, варто було як у цьому Кодексі, так і додатках до ПВР УВП чітко вказати перелік, зокрема, продуктів харчування, які засуджені можуть тримати при собі.

Такий підхід повністю корегувався б зі змістом частини другої статті 107 КВК, у якій зазначено, що засудженим до позбавлення волі можуть надаватися й інші права, реалізація яких не суперечить меті покарання, порядку та умовам виконання і відбування даного покарання.

2.У розділі ІІ ПВР УВП зазначено, що засуджені до позбавлення волі мають право користуватися ву приміщеннях для вживання їжі та зберігання продуктів харчування електричними чайниками та мікрохвильовими печами, які придбали за власний рахунок або рахунок родичів.

Ураховуючи зазначене, слід констатувати, що заборона щодо продуктів харчування, які потребують термічної обробки, є дещо нелогічною, зокрема якщо засуджений придбав їх у крамниці УВП, яка має відповідний сертифікат якості та виступає гарантом безпеки їх вживання.

Поряд із цим необхідно зазначити, що в статтях 107, 108 КВК право засуджених на користування електричними чайниками, «мікрохвильовками», холодильниками тощо не закріплено, тобто у ПВР УВП дано розширене тлумачення (роз'яснення, яке виходить за межі змісту цих правових норм), що суперечить пункту 14 статті92 Конституції України, відповідно до якої виключно законами визначається право осіб (та загалом - їх статус). 
До того ж ані в КВК (стаття 115 «Матеріально-побутове забезпечення засуджених до позбавлення волі»), ані в ПВР УВП (розділ XXII) не йдеться про приміщення для вживання їжі та зберігання продуктів харчування, про що згадується в розділі XXII ПВР УВП, а тому зазначену прогалину слід ліквідувати шляхом доповнення цих Правил відповідним положення про порядок обладнання приміщень для вживання їжі та зберігання продуктів харчування засудженими в місцях позбавлення волі.

3.У частині третій статті 63 Конституції України зазначено, що засуджений користується всіма правами людини і громадянина, за винятком обмежень, які визначені законом і встановлені вироком суду.

Аналогічне положення закріплено і в частинах другій та четвертій статті 7 КВК: правовий статус засуджених визначається законами України, а також цим Кодексом, виходячи 3 порядку та умов виконання і відбування конкретного виду покарання.

Ураховуючи зазначене, логічно було б частину першу статті 107 КВК доповнити тим переліком продуктів харчування, який визначений в додатку 5 ПВР УВП, позаяк на рівні підзаконних нормативно-правових актів (до яких, зокрема, належать i вказані Правила) вводити правообмеження для засуджених не можна.

Як з цього приводу зазначено в пункті 5 постанови Пленуму Верховного Суду України від 01.11.1996 р. № 9 «Про застосування Конституції України при здійсненні правосуддя», якщо при розгляді справи буде встановлено, що нормативно-правовий акт, який підлягав застосуванню, не відповідає чи суперечить законові, суд зобов'язаний застосувати закон, який регулює ці правовідносини [8, c. 137].

4. Як свідчить практика виконання покарання у виді позбавлення волі, однією з умов, що призводить до вчинення засудженими таких злочинів, як злісна непокора адміністрації установ виконання покарань (стаття 391 КК України), та дій, що дезорганізують роботу установ виконання покарань (стаття 392 КК України), $\epsilon$ недотримання персоналом колоній порядку надання послуг та забезпечення права засуджених на відповідне та якісне харчування, норми якого встановлюються Кабінетом Міністрів України (частина п'ята статті 115 КВК).

Водночас ані в статті 8 «Основні права засуджених», ані в статті 107 «Права і обов'язки засуджених до позбавлення волі», ані в статті 115 «Матеріально-побутове забезпечення засуджених до позбавлення волі» КВК України, ані в тих же нормах ПВР УВП жодним словом не згадано про право цих осіб на якісне харчування, норми якого визначаються законом (пункт 14 статті 92 Конституції України).

Ураховуючи зазначену обставину та прогалину в законі, як одна сторона (адміністрація УВП), так і інша сторона (засуджені) використовують ï при вирішенні тих чи інших конфліктних ситуацій, що виникають між ними в ході виконання - відбування покарання у виді позбавлення волі. Так, у 1991 році саме 3 цього приводу мали місце групові відмови засуджених від роботи та прийому їжі в УВП Вінницької, Дніпропетровської, Київської, Кіровоградської, Львівської, Миколаївської, Полтавської, Херсон- 
ської, Хмельницької та Черкаської областей, тобто в більшості колоній України [9, с. 2].

Аналогічні події були зареєстровані і в наступні роки. Зокрема, у 2011 році (першому звітному періоді після підпорядкування органів та установ виконання покарань Міністерству юстиції України) 31 засуджений за позбавлення волі Дніпропетровської виправної колонії № 89 письмово відмовився від уживання їжі, мотивуючи це, у тому числі, й неякісним харчуванням, організованим адміністрацією цієї УВП [10, c. 5].

У 2015 році 3 таких самих причин відбулася групова відмова від уживання їжі засудженими в Солонянській виправній колонії № 21 та Ірпінському виправному центрі № $132[11$, c. 4$]$.
Висновки. Отже, виходячи 3 наведеного аналізу, необхідно констатувати, що існує складна теоретикоприкладна проблема, яка безпосередньо стосується забезпечення природного права людини на якісне і повноцінне харчування, включаючи й засуджених до позбавлення волі, та потребує невідкладного вирішення, у тому числі на нормативно-правовому рівні, позаяк зволікання з урегулюванням цього питання відповідними нормами закону не дозволяє належним чином блокувати, нейтралізувати, усунути тощо ті де термінанти, що спричиняють скоєння нових злочинів, обумовлених проблемами неякісного забезпечення права засуджених на харчування, особами, які відбувають покарання в місцях позбавлення волі.

\section{Список використаних джерел}

1. Про приведення умов тримання засуджених до позбавлення волі до Європейських стандартів : Закон України від 14 квітня 2014 року. Голос України. 06.05.2014. № 87.

2. Про схвалення Концепції реформування (розвитку) пенітенціарної системи України: розпорядження Кабінету Міністрів України від 17 вересня 2017 року. Урядовий кур'єр. 22.09.2017 р. № 178.

3. Європейські пенітенціарні правила : Рекомендація ради Європи R(2006)2. Вид. 2-ге. Донецьк : «Донецький меморіал», 2010. 32 с.

4. Бущенко А.П. Проти катувань. Аналіз відповідності українського законодавства та практики стандартам і рекомендаціям Європейського комітету запобігання катуванням та жорстокому поводженню. Харків : Права людини; Харківська правозахисна група, 2005. 240 с.

5. Огляд рішень Європейського суду з прав людини. Донецьк : «Донецький меморіал», 2011. 55 с.

6. Кримінально-виконавчий кодекс України. Правила внутрішнього розпорядку установ виконання покарань: офіційні тексти. Київ : Алерта, 2019. 220 с.

7. Конституція України : офіційний текст. Київ : Алерта, 2019. 80 с.

8. Про застосування Конституції України при здійсненні правосуддя : постанова Пленуму Верховного Суду України від 01.11.1996 р. № 9. Постанова Пленуму Верховного Суду України у кримінальних справах / упоряд. В. В. Рожнова, А. С. Сизоненко, Л. Д. Удалова. Київ : ПАЛИВОДА А. В., 2011. С. 136-141.

9. Некоторые показатели деятельности учреждений уголовно-исполнительной системы МВД Украины в 1991 году. Киев : ГУИН МВД Украины, 1992. 28 с. 
10. Про діяльність підрозділів охорони, нагляду і безпеки кримінальновиконавчих установ у 2011 році : Інформ. бюлетень. Київ : ДПтС України, 2011. 69 с.

11. Про діяльність підрозділів охорони, нагляду і безпеки кримінальновиконавчих установ у 2015 році. Київ : ДПтС України, 2016. 59 с.

\section{References}

1. Pro privedennya umov trimannya zasudzhenih do pozbavlennya voli do Yevropejskih standartiv: Zakon Ukrayini vid 14 kvitnya 2014 roku. Golos Ukrayini. 06.05.2014. № 87 [in Ukrainian].

2. Pro shvalennya Koncepciyi reformuvannya (rozvitku) penitenciarnoyi sistemi Ukrayini: rozporyadzhennya Kabinetu Ministriv Ukrayini vid 17 veresnya 2017 roku. Uryadovij kur'yer. 22.09.2017 r. № 178[in Ukrainian].

3. Yevropejski penitenciarni pravila : Rekomendaciya radi Yevropi R(2006)2. Vid. 2-ge. Doneck: «Doneckij memorial» (2010) [in Ukrainian].

4. Bushenko, A. P. (2005). Proti katuvan. Analiz vidpovidnosti ukrayinskogo zakonodavstva ta praktiki standartam i rekomendaciyam Yevropejskogo komitetu zapobigannya katuvannyam ta zhorstokomu povodzhennyu. Harkiv: Prava lyudini; Harkivska pravozahisna grupa [in Ukrainian].

5. Oglyad rishen Yevropejskogo sudu z prav lyudini. Doneck : «Doneckij memorial» (2011) [in Ukrainian].

6. Kriminalno-vikonavchij kodeks Ukrayini. Pravila vnutrishnogo rozporyadku ustanov vikonannya pokaran: ofic. teksti. Kiyiv: Alerta. (2019) [in Ukrainian].

7. Konstituciya Ukrayini: chinne zakonodavstvo stanom na 16 sichnya 2019 r.: Ofic. tekst. Kiyiv: Alerta [in Ukrainian].

8. Pro zastosuvannya Konstituciyi Ukrayini pri zdijsnenni pravosuddya : postanova Plenumu Verhovnogo Sudu Ukrayini vid 01.11.1996 r. № 9. Postanova Plenumu Verhovnogo Sudu Ukrayini u kriminalnih spravah. Uklad. V. V. Rozhnova, A. S. Sizonenko, L. D. Udalova. Kiyiv: PALIVODA A. V. [in Ukrainian].

9. Nekotorye pokazateli deyatelnosti uchrezhdenij ugolovno-ispolnitelnoj sistemy MVD Ukrainy v 1991 godu. Inform. byulleten. Kiev: GUIN MVD Ukrainy, 1992 [in Ukrainian].

10. Pro diyalnist pidrozdiliv ohoroni, naglyadu i bezpeki kriminalno-vikonavchih ustanov u 2011 roci: Inform. byuleten. Kiyiv : DPtS Ukrayini, 2011 [in Ukrainian].

11. Pro diyalnist pidrozdiliv ohoroni, naglyadu i bezpeki kriminalno-vikonavchih ustanov u 2015 roci. Kiyiv: DPtS Ukrayini, 2016 [in Ukrainian].

E. Makhnitskaya, Postgraduate Student of Department of criminal right and justice of International Universityof Economics and Humanities Academician Stepan Demianchuk

\section{On the social and legal nature of prohibitions regarding food for convicts, imprisoned they have the right keep with them}

The article analyzes the norms of criminal-executive law that relate to prohibitions on products and substances that convicts can receive in packages, buy in shops of penitentiary institutions and keep for themselves, and also developed scientifically based proposals aimed at reducing their list at the regulatory level.

In April 2014, Ukraine adopted a series of amendments to the penal legislation aimed at bringing the conditions of execution - serving a sentence of impris- 
onment to European standards. The relevant mechanisms for the implementation of this task are defined, in particular, in the Concept of reforming (development) of the penitentiary system of Ukraine, approved by the decree of the Cabinet of Ministers of Ukraine in September 2017. At the same time, one of the systemic requirements imposed by the European Community on Ukraine is a significant improvement in the nutrition of persons held in detention facilities. Important in this respect is the provision of the European Prison Rules (hereinafter referred to as the EPC), which states in paragraph 22.1 that prisoners should be provided with a complete diet, taking into account their age, health, religion, culture and the nature of their work. At the same time, nutrition requirements, including the minimum amount of calories and proteins, are determined by national law.

However, as practice shows, the very issue of nutrition for prisoners serving imprisonment in Ukraine is always subject to negative evaluation by relevant international experts and decisions of the European Court of Human Rights (EU PP). In this context, the object of criticism in this context is also defined in the rules of the criminal law of the prohibition of certain types of foodstuffs that prisoners have the right to keep with them (imprisonment) (h. 7 Article 102, Article 108, 112 - the Code of Enforcement (CCC) and Annexes 3, 5 to the Rules of Internal Order of Penitentiary Establishments (JIU of Penitentiary).

Keywords: prohibited foods, products and substances; convicted; deprivation of liberty; colony personnel; the right of the person; the duty of the person; penal legislation.

Надійшла до редакції 08.08.2019 